\title{
Association between coping styles of adolescents with type 1 diabetes and metabolic control.
}

\author{
${ }^{1} \mathrm{~F}$. Karachaliou, ${ }^{1}$ V. Petrou, ${ }^{1} \mathrm{Ch}$. Drosatou, ${ }^{1} \mathrm{I}$ Kaloumenou, ${ }^{2} \mathrm{~B}$. Kandyla, ${ }^{1} \mathrm{~S}$ Michalakos, ${ }^{2} \mathrm{~K}$. Karavanaki \\ ${ }^{1}$ Endocrinology Department-Department of Growth and Development, "P\&A Kyriakou" Children's Hospital, Athens, Greece. \\ 2Diabetic Clinic, $2^{\text {nd }}$ Department of Pediatrics, University of Athens, "P\&A Kyriakou" Children's Hospital, Athens, Greece.
}

\section{INTRODUCTION}

Coping styles refer to habitual ways of approaching problems and may be regarded as strategies that people use to cope across a wide range of stressors

$>$ Problem-focused coping refers to efforts directed towards rational management of the problem and it is aimed to change the stressful situation

$>$ Emotion-focused coping refers to efforts towards reducing the emotional distress and regulate emotions that result from the stressor Across different chronic diseases, it has been shown that problem focused coping is generally associated with better adjustment

In adolescents with diabetes, coping styles have been identified as important factors in the management of the disease.

A relationship between higher levels of avoidance coping and poorer metabolic control has been demonstrated

\section{AlM}

To study the various coping behaviors in a sample of children and adolescents with T1DM and to evaluate their association with metabolic control and duration of disease.

\section{METHODS}

65 adolescents with T1DM (male/female:22/43)

$>$ mean $( \pm S D)$ age of $12.6( \pm 2.2)$ years,

$>$ disease duration of $4.8( \pm 2.4)$ years

$>\mathrm{HbA} 1 \mathrm{c}$ of $8.1( \pm 1.6) \%$,

who attended the diabetic clinic of the University Department of a

Tertiary Children's Hospital.

The "Ways of Coping Questionnaire" (Lazarus and Folkman), adapted and validated in Greek population, was completed by all adolescents, 36 fathers $(67.9 \%)$ and 17 mothers $(32.1 \%)$.

Coping was categorized as:

a. active coping (I knew that it had to be done, so I doubled my efforts, I tried to see the positive side of things)

b. seeking social support (I discussed with someone to help me understand more about the situation, I discussed with someone who would do something specific for me)

c. wishful thinking (I wished the problem would go off, I prayed...)

d. problem avoidance (I was trying not to take it seriously, I was trying to forget the problem by working or doing sth else)

e. aggressive coping (I got irritated, I expressed my anger to the person responsible for the problem)

Table 1 Characteristics of patients with T1DM

\begin{tabular}{|l|l|l|}
\hline & Males & $22(33.8 \%)$ \\
\hline & Females & $43(66.2 \%)$ \\
\hline Age (yrs) & & $12.6(2.2)$ \\
\hline Duration (yrs) & & $4.8(2.4)$ \\
\hline Living with both parents & yes & $13(20 \%)$ \\
\hline & no & $52(80 \%)$ \\
\hline HbA1c(\%) & & $8.1(1.6)$ \\
\hline Insulin regimen & conventional & $3(4.6 \%)$ \\
\hline & multiple injection & $58(89.2 \%)$ \\
\hline & pump & $4(6.1 \%)$ \\
\hline Concomitant disease & & $24(47.1 \%)$ \\
\hline & Microalbuminuria & $8(15.7 \%)$ \\
\hline & Thyroiditis & $13(25.5 \%)$ \\
\hline & Celiac disease & $3(5.9 \%)$ \\
\hline Person who filled the & Autoimmune gastritis & $3(5.9 \%)$ \\
\hline questionnaire & Father & $36(67.9 \%)$ \\
Mother & $17(32.1 \%)$ \\
\hline
\end{tabular}

\section{RESULTS}

There was a significant association between parents' and adolescents coping styles in respect of "active coping" and "seeking social support" (table 2)

\begin{tabular}{|c|c|c|c|c|c|c|}
\hline ADOLESCENTS & & & & PARENT & & \\
\hline \multirow{3}{*}{ Active coping } & & $\begin{array}{l}\text { Active } \\
\text { coping }\end{array}$ & $\begin{array}{l}\text { Seeking } \\
\text { social } \\
\text { support }\end{array}$ & $\begin{array}{l}\text { Wishful } \\
\text { thinking }\end{array}$ & \begin{tabular}{|l} 
Problem \\
avoidance
\end{tabular} & $\begin{array}{l}\text { Aggressive } \\
\text { coping }\end{array}$ \\
\hline & $r$ & 0.41 & & & & \\
\hline & $p$ & 0.016 & & & & \\
\hline \multirow{2}{*}{$\begin{array}{l}\text { Seeking social } \\
\text { support }\end{array}$} & $r$ & & 0.38 & & & \\
\hline & $p$ & & 0.023 & & & \\
\hline \multirow{2}{*}{$\begin{array}{l}\text { Wishful } \\
\text { thinking }\end{array}$} & $r$ & & & 0.03 & & \\
\hline & $p$ & & & 0.863 & & \\
\hline \multirow{2}{*}{$\begin{array}{l}\text { Problem } \\
\text { avoidance }\end{array}$} & $\mathbf{r}$ & & & & -0.11 & \\
\hline & $p$ & & & & 0.522 & \\
\hline \multirow{2}{*}{$\begin{array}{l}\text { Aggressive } \\
\text { coping }\end{array}$} & $\mathbf{r}$ & & & & & 0.28 \\
\hline & p & & & & & 0.109 \\
\hline
\end{tabular}

Female adolescents used more the "seeking social support" way compared to males (table 3 )

Table 3 Difference in coping styles between boys and girls with T1DM

\begin{tabular}{|l|l|l|l|}
\hline & \multicolumn{2}{|c|}{ Sex } & \\
\hline & Males & Females & \\
\hline & Mean (sd) & Mean (sd) & $p$ \\
\hline Active coping & $1.80(0.70)$ & $1.88(0.52)$ & 0.668 \\
\hline Seeking social support & $1.39(0.99)$ & $1.92(0.73)$ & 0.041 \\
\hline Wishful thinking & $1.21(0.83)$ & $1.58(0.81)$ & 0.140 \\
\hline Problem avoidance & $1.35(0.52)$ & $1.57(0.53)$ & 0.184 \\
\hline Aggressive coping & $1.17(0.38)$ & $1.34(0.60)$ & 0.326 \\
\hline
\end{tabular}

Duration of disease was positively associated with the "active coping" style. Mean $\mathrm{HbA} 1 \mathrm{c}$ levels were positively correlated with aggressive coping" and negatively associated with "active coping" (table 4)

Table 4. Partial correlation coefficients between coping styles and disease duration and glycaemic control

\begin{tabular}{|l|l|l|l|}
\hline \multirow{2}{*}{ Active coping } & & Duration (yrs) & HbA1c (\%) \\
\hline \multirow{2}{*}{ Seeking social support } & $\mathrm{r}$ & 0.36 & -0.031 \\
\cline { 2 - 4 } & $\mathrm{p}$ & 0.014 & 0.035 \\
\hline \multirow{2}{*}{ Wishful thinking } & $\mathrm{r}$ & 0.00 & -0.12 \\
\cline { 2 - 4 } & $\mathrm{p}$ & 0.977 & 0.412 \\
\hline Problem avoidance & $\mathrm{r}$ & -0.03 & 0.26 \\
\cline { 2 - 4 } & $\mathrm{p}$ & 0.848 & 0.079 \\
\hline Aggressive coping & $\mathrm{r}$ & -0.16 & -0.02 \\
\cline { 2 - 4 } & $\mathrm{p}$ & 0.277 & 0.911 \\
\hline & $\mathrm{r}$ & 0.1 & 0.36 \\
\cline { 2 - 4 } & $\mathrm{p}$ & 0.529 & 0.014 \\
\hline
\end{tabular}

\section{CONCLUSIONS}

Active coping was associated with better metabolic control and longer diabetes duration in adolescents with T1DM.

Female adolescents with T1DM used more the "seeking social support" strategy compared to males, which is also reported in healthy adolescents

Assessment of coping behavior might be useful in the identification of adolescents in need of particular support and counseling. 